\title{
Co-Infections in Children Hospitalised for Bronchiolitis: Role of Roomsharing
}

\author{
Jolita Bekhof a, c , Joline Bakker ${ }^{\mathrm{a}}$, Roelien Reimink ${ }^{\mathrm{a}}$, Mirjam Wessels ${ }^{\mathrm{a}}$, \\ Veerle Langenhorst ${ }^{\mathrm{a}}$, Paul L.P. Brand ${ }^{\mathrm{a}}$, Gijs J.H.M. Ruijs ${ }^{\mathrm{b}}$
}

\begin{abstract}
Background: Bronchiolitis is a major cause for hospitalisation in young children during the winter season, with respiratory syncytial virus (RSV) as the main causative virus. Apart from standard hygiene measures, cohorting of RSV-infected patients separately from RSV-negative patients is frequently applied to prevent crossinfection, although evidence to support this practice is lacking. The objective is to evaluate the risk of room sharing between RSV-positive and RSV-negative patients.
\end{abstract}

Methods: We performed a prospective observational cohort study in children $<2$ years hospitalised with acute bronchiolitis. During the first day of admission, patients shared one room, pending results of virological diagnosis (PCR). When diagnostic results were available, RSV-positive and RSV-negative patients were separated. Standard hygienic measures (gowns, gloves, masks, hand washing) were used in all patients.

Results: We included 48 patients ( $83 \%$ RSV-positive). Co-infection was found in nine patients at admission, and two during hospitalisation (23\%). The two patients with acquired co-infection had been nursed in a single room during the entire admission. None of 37 patients sharing a room with other bronchiolitis patients (20 with patients with a different virus) were co-infected during admission. Disease severity in co-infection was not worse than in monoinfection.

Conclusion: One in five patients with bronchiolitis was co-infected, but co-infection acquired during admission was rare and was not associated with more severe disease. Room sharing between RSV-positive and RSV-negative patients (on the first day of admission) did not influence the risk of co-infection, suggesting that co-

Manuscript accepted for publication August 23, 2013

aPrincess Amalia Children's Clinic, Isala klinieken, Zwolle, The Netherlands

${ }^{b}$ Laboratory for Clinical Microbiology and Infectious Diseases, Isala klinieken, Zwolle, The Netherlands

'Corresponding author: Jolita Bekhof, Princess Amalia Children's

Clinic, Isala klinieken, Dr van Heesweg 2, PO Box 10400, 8000 GK

Zwolle, The Netherlands. Email: j.bekhof@isala.nl

doi: http://dx.doi.org/10.4021/jocmr1556w horting of RSV-infected patients separate from non-RSV-infected patients may not be indicated.

Keywords: Respiratory syncytial virus; Isolation; Cross infections; Transmission; Nosocomial; Cohorting

\section{Introduction}

Acute bronchiolitis is a major cause for hospitalisation in young children during the winter season $[1,2]$. Human Respiratory Syncytial Virus (RSV) is the most frequently identified virus, however with the use of new and highly sensitive molecular amplification methods, the role of other viral pathogens in bronchiolitis has been increasingly recognized. Various disease severity has been shown for a range of respiratory viruses, and double viral infection is relatively common, occurring in about $10-30 \%$ of hospitalised patients [3-7]. There is no consensus, however, on the impact of such co-infection on disease severity [5]: Some studies showed more severe disease in co-infected children [8-14], while others did not [15-21]. Most hospitals perform routine viral testing to identify and isolate RSV-infected infants, with the aim of reducing the risk of nosocomial cross-infection of other patients [22-24]. However, no good evidence is available of how effective this approach is in preventing nosocomial cross-infections among admitted patients with the clinical diagnosis of bronchiolitis.

Because of limited isolation facilities, patients with bronchiolitis admitted to our pediatric ward initially share a room, pending the results of virologicall diagnosis. We hypothesize that contact isolation measures and maintaining enough distance between the beds in a shared room should be sufficient in preventing cross-infection, since the major route of transmission of respiratory viruses is by close contact with infected secretions and not by small-particle aerosol $[24,25]$.

\section{Objectives}

The purpose of this study was to determine the incidence 
Table 1. Dyspnoea Score

\begin{tabular}{llll}
\hline & $\mathbf{0}$ & $\mathbf{1}$ & $\mathbf{2}$ \\
\hline Respiratory rate & $\begin{array}{l}\text { normal } \\
<40 / \mathrm{min}\end{array}$ & $\begin{array}{l}\text { slightly increased } 40-60 / \\
\text { min }\end{array}$ & $\begin{array}{l}\text { clearly increased } \\
>60 / \mathrm{min}\end{array}$ \\
Oxygen saturation & $\geq 95 \%$ in room air & $\begin{array}{l}92-94 \% \text { in room air } \\
\text { Wheezing }\end{array}$ & $\begin{array}{l}<92 \% \text { in room air, or need for } \\
\text { supplemental oxygen }\end{array}$ \\
Retractions & none & audible with stethoscope & audible without stethoscope \\
General condition & $\begin{array}{l}\text { not affected: } \\
\text { alert/quietly } \\
\text { sleeping }\end{array}$ & $\begin{array}{l}\text { mild-moderate } \\
\text { Irritable or agitated }\end{array}$ & $\begin{array}{l}\text { severe } \\
\text { severely affected: } \\
\text { lethargic, poor feeding }\end{array}$ \\
\hline
\end{tabular}

Adapted from Kristiansson [27].

of cross-infection in children hospitalised for bronchiolitis, when patients with RSV share the same room with patients with bronchiolitis infected with another virus during the first day of admission.

\section{Table 2. Patient Characteristics}

$$
\mathrm{n}=48
$$

Age, months

Male

Birth characteristics

$$
\begin{aligned}
& \text { gestational age, weeks } \\
& \text { preterm birth }(<37 \text { weeks) }
\end{aligned}
$$$$
\text { birth weight, gram }
$$$$
3.2(1.8-9.7)
$$$$
26(54.2 \%)
$$

$2(4.2 \%)$

$3420(3,120-3,740)$

Environmental factors

$$
\begin{aligned}
& \text { day care attendance } \\
& \text { siblings }
\end{aligned}
$$$$
16(33.3 \%)
$$

Disease severity

$$
\begin{array}{ll}
\text { length of hospitalization (days) } & 1.9(1.6-4.0) \\
\text { oxygen supplementation } & 30(62.5 \%) \\
\text { tubefeeding } & 20(41.7 \%) \\
\text { highest dyspnoea score }(0-10) & 3.0(2.0-4.8) \\
\text { mechanical ventilation } & 3 *(6.2 \%)
\end{array}
$$

Data are presented as median and interquartile range in parentheses, or number and percentage in parentheses; Highest possible dyspnoea score $10 ;{ }^{*}$ all 3 patients mono-infected with RSV. 
Table 3. Distribution of Viral Pathogens

\begin{tabular}{|c|c|c|c|}
\hline Virus & $\begin{array}{l}\text { At admission } \\
n=48\end{array}$ & $\begin{array}{l}\text { At discharge } \\
\mathrm{n}=48\end{array}$ & $\begin{array}{l}\text { After discharge } \\
\mathrm{n}=44\end{array}$ \\
\hline \multicolumn{4}{|l|}{ Mono-infections } \\
\hline RSV-A & $7(14.5 \%)$ & $6(12.5 \%)$ & $2(4.5 \%)$ \\
\hline RSV-B & $25(52.1 \%)$ & $19(39.6 \%)$ & $5(11.4 \%)$ \\
\hline hMPV & $2(4.2 \%)$ & $1(2.1 \%)$ & $1(2.3 \%)$ \\
\hline $\mathrm{RhV}$ & $3(6.3 \%)$ & $3(.3 \%)$ & $3(6.8 \%)$ \\
\hline $\mathrm{CoV}$ & 0 & $2(4.2 \%)$ & $1(2.3 \%)$ \\
\hline $\mathrm{AdV}$ & 0 & 0 & $3(6.8 \%)$ \\
\hline \multicolumn{4}{|l|}{ Co-infections } \\
\hline RSV-A and hMPV & $1(2.1 \%)$ & $1(2.1 \%)$ & 0 \\
\hline \multicolumn{4}{|l|}{ RSV-B and } \\
\hline PIV & $1(2.1 \%)$ & 0 & 0 \\
\hline $\mathrm{AdV}$ & 0 & $1(2.1 \%)$ & 0 \\
\hline RhV & $4(8.3 \%)$ & $4(8.3 \%)$ & $1(2.3 \%)$ \\
\hline $\mathrm{CoV}$ & $1(2.1 \%)$ & 0 & 0 \\
\hline hMPV & $1(2.1 \%)$ & $1(2.1 \%)$ & 0 \\
\hline $\mathrm{CoV}$ and PIV & $1(2.1 \%)$ & $1(2.1 \%)$ & 0 \\
\hline No virus & $2(4.2 \%)$ & $9(18.8 \%)$ & $28(63.6 \%)$ \\
\hline
\end{tabular}

Number with percentage in parentheses; RSV: Respiratory Syncytial; hMPV: human MetaPneumo Virus; RhV: Rhino Virus; CoV: Corona Virus; AdV: Adeno Virus; PIV: Parainfluenza Virus.

\section{Materials and Methods}

The study was conducted at our 30-bed pediatric ward. From December 2011 through March 2012, all eligible infants younger than two years of age hospitalised for acute bronchiolitis were prospectively enrolled. Bronchiolitis was defined as acute respiratory disease, accompanied by coryza, cough, inspiratory crackles and/or expiratory wheezing on auscultation. Infants with chronic lung disease, congenital heart disease and Down's syndrome were excluded.

We prospectively collected the following demographic and clinical information, including presence and number of room mates, virological diagnosis of the patient and room mates, and daily dyspnoea score assessed by an independent researcher, who was unaware of virological diagnosis (Table 1) $[26]$.

A nasopharyngeal aspirate was collected for virological diagnosis by direct immunochromatographic antigen detection (RespiFinder TwoStep kit, Pathofinder) immediately at admission, every fourth day during admission, and five to seven days after discharge [27, 28].

All patients with bronchiolitis were treated with standard hygienic measures. Medical and nursing personnel wore gowns, gloves and masks during patient contact and washed their hands before and after patient contact. Parents and visitors were asked to wash hands before leaving the room. On the first day of admission, pending the results of the RSV-PCR, patients shared a two- or four-bed room, with beds separated at least 1.5 meter. Cohorting of RSV-infected patients commenced as soon as the result of RSV-PCR was known, generally within one day after admission.

\section{Statistical analysis}

Chi-square test was used to compare categorical data, MannWhitney U-tests for continuous data because of skewed distributions. Statistical analyses were performed using Statistical Package for the Social Sciences (SPSS) version 19. 
Table 4. Comparison of Disease Severity Between Mono- Versus Co-Infected Patients and RSV-Infected Versus RSVUninfected Patients

\begin{tabular}{|c|c|c|c|c|c|c|}
\hline \multirow{2}{*}{$\mathrm{n}=48$} & \multicolumn{3}{|c|}{ Mono versus co-infection } & \multicolumn{3}{|c|}{ RSV-infected versus RSV-uninfected } \\
\hline & $\begin{array}{l}\text { Co-infection } \\
n=11\end{array}$ & $\begin{array}{l}\text { Mono-infection } \\
\mathbf{n}=\mathbf{3 7}\end{array}$ & P-value & $\begin{array}{l}\text { RSV-infected } \\
n=40\end{array}$ & $\begin{array}{l}\text { RSV-uninfected } \\
n=8\end{array}$ & P-value \\
\hline Age, months & $4.3(2.2-11.4)$ & $3.2(1.6-9.4)$ & 0.413 & $3.3(1.8-9.8)$ & $3.0(1.6-8.5)$ & 0.740 \\
\hline $\begin{array}{l}\text { Length of } \\
\text { hospitalization, days }\end{array}$ & $2.0(1.7-3.4)$ & $1.9(1.2-4.2)$ & 0.864 & $2.5(1.6-4.4)$ & $1.8(1.2-1.9)$ & 0.162 \\
\hline $\begin{array}{l}\text { Oxygen } \\
\text { supplementation }\end{array}$ & $6(54.6 \%)$ & $24(64.9 \%)$ & 0.535 & $25(62.5 \%)$ & $5(62.5 \%)$ & 1.000 \\
\hline Tubefeeding & $4(36.4 \%)$ & $16(43.2 \%)$ & 0.681 & $18(45.0 \%)$ & $2(25 \%)$ & 0.295 \\
\hline $\begin{array}{l}\text { Highest dyspnoea } \\
\text { score }(0-10)\end{array}$ & $3.0(2.0-4.0)$ & $3.0(1.5-5.0)$ & 0.654 & $3.0(2.0-5.0)$ & $2.5(1.0-4.0)$ & 0.285 \\
\hline $\begin{array}{l}\text { Mechanical } \\
\text { ventilation }\end{array}$ & $1(9.1 \%)$ & $2(5.4 \%)$ & 0.658 & $3(7.5 \%)$ & $0(0 \%)$ & 0.424 \\
\hline
\end{tabular}

Data are presented as median and interquartile range in parentheses, or number and percentage in parentheses as appropriate; $\mathrm{P}$ value: Mann-Whitney-U test for continuous variables, $X^{2}$ test for dichotomous variables.

Thisstudyisregistered atclinicaltrials.gov(NCT01441466).

\section{Results}

Of the 84 patients with bronchiolitis hospitalised during the 11 -week study period, 36 were excluded for the following reasons: cardiac disease (2), chronic lung disease with home oxygen (2), Down's syndrome (3), no parental consent (12), age $>$ two (7), missed inclusion (6), missing nasal wash specimen at admission (3). A total of 48 patients completed the study (Table 2).

The distribution of viral pathogens is shown in Table 3; RSV was the major pathogen detected in $83 \%$. Co-infection was found in $11(22.9 \%)$ patients, nine of whom were already co-infected at admission, and two acquired co-infection during admission.

Of all included patients, 37 (77.1\%) had shared a room with other bronchiolitis patients, 20 of whom $(54.1 \%)$ had shared a room with a patient infected with a different virus. The two patients who acquired co-infection during admission had never shared a room with another patient. None of the bronchiolitis-patients sharing rooms had been infected with another virus during admission.

Co-infected patients did not suffer from more severe disease than patients infected with a single virus, but, al- though not statistically significant, disease severity tended to be higher in RSV-infected patients compared to RSV-negative patients (Table 4).

\section{Discussion}

This study showed that nosocomially acquired co-infection is rare, even when RSV-positive and RSV-negative patients share a room during the first day of hospital admission. Furthermore, co-infection was not associated with more severe disease. The small number of our study limits any firm conclusion, however these findings may suggest that separating RSV-infected from RSV-negative patients with bronchiolitis may not be indicated. Cohorting of patients with bronchiolitis as one group, irrespective of viral diagnosis, may suffice.

Our finding that cohorting of RSV-infected patients may not add to the prevention of co-infection is supported by the fact that the main route of transmission of respiratory viruses is through direct contact, with only a minor role for aerosol transmission $[24,25]$. Therefore, we stress that strict adherence to other hygienic measures by medical staff and patient's relatives is clearly of crucial importance [23, 24]. Hand washing is the single most important procedure in the prevention of nosocomial infections, yet it remains the most violated of all infection control procedures [23, 24]. It is con- 
ceivable that placing children in a cohort generates considerable peer and parental pressure to ensure that measures such as hand washing are followed.

Our results may also imply that routinely performing virological diagnostic testing is not needed in children with bronchiolitis. The diagnosis of bronchiolitis is a clinical diagnosis and for this purpose further diagnostic testing is not needed [29]. Since cohorting of RSV-infected patients is the most importance reason for virological testing in bronchiolitis, health care expenses can be reduced by omitting the routine use of these tests, provided that influenza, a serious and treatable infection, is excluded.

This does not exclude the potential usefulness of rapid broad range viral testing in specific circumstances, for example in young febrile infants, where rapid broad range viral testing might reduce the need for invasive sepsis workup, or in case of unclear clinical presentation (apnoea without respiratory signs) or for surveillance purposes.

Our findings add to the current controversy considering this issue and we realise that the small numbers of our study limit solid comments on this subject and no definite conclusions can be made. Another important limitation is the fact that we only evaluated the risk of room sharing during the first 24 hours of admission. It is well possible that prolonged sharing of rooms increases the incidence of cross-infections. For practical and safety reasons, we deliberately chose to perform the study under these specific circumstances as a proof of principle, before embarking on a similar project with room sharing during the entire admission.

We conclude that, with standard hygiene control measures, the risk of nosocomially acquired co-infection is low, and does not appear to be related to room sharing between RSV-positive and RSV-negative patients (during the first day of admission). These findings argue against routine cohorting of RSV-infected bronchiolitis patients and against routinely carrying out broad range virological testing of infants hospitalised for bronchiolitis. Yet a larger number of patients, applying room sharing during the entire admission is needed before definite conclusions can be made.

\section{Funding}

None.

\section{Competing Interests}

None declared.

\section{Ethical Approvement}

Written informed consent from the parents was obtained be- fore inclusion. The study was approved by the institutional's ethical review board.

\section{References}

1. Smyth RL, Openshaw PJ. Bronchiolitis. Lancet. 2006;368(9532):312-322.

2. Bush A, Thomson AH. Acute bronchiolitis. BMJ. 2007;335(7628):1037-1041.

3. Paranhos-Baccala G, Komurian-Pradel F, Richard N, Vernet G, Lina B, Floret D. Mixed respiratory virus infections. J Clin Virol. 2008;43(4):407-410.

4. Schuh S. Update on management of bronchiolitis. Curr Opin Pediatr. 2011;23(1):110-114.

5. Tregoning JS, Schwarze J. Respiratory viral infections in infants: causes, clinical symptoms, virology, and immunology. Clin Microbiol Rev. 2010;23(1):74-98.

6. Ray CG, Minnich LL, Holberg CJ, Shehab ZM, Wright AL, Barton LL, Taussig LM. Respiratory syncytial virus-associated lower respiratory illnesses: possible influence of other agents. The Group Health Medical Associates. Pediatr Infect Dis J. 1993;12(1):15-19.

7. Drews AL, Atmar RL, Glezen WP, Baxter BD, Piedra PA, Greenberg SB. Dual respiratory virus infections. Clin Infect Dis. 1997;25(6):1421-1429.

8. Greensill J, McNamara PS, Dove W, Flanagan B, Smyth RL, Hart CA. Human metapneumovirus in severe respiratory syncytial virus bronchiolitis. Emerg Infect Dis. 2003;9(3):372-375.

9. Semple MG, Cowell A, Dove W, Greensill J, McNamara PS, Halfhide C, Shears P, et al. Dual infection of infants by human metapneumovirus and human respiratory syncytial virus is strongly associated with severe bronchiolitis. J Infect Dis. 2005;191(3):382-386.

10. Richard N, Komurian-Pradel F, Javouhey E, Perret M, Rajoharison A, Bagnaud A, Billaud G, et al. The impact of dual viral infection in infants admitted to a pediatric intensive care unit associated with severe bronchiolitis. Pediatr Infect Dis J. 2008;27(3):213-217.

11. Foulongne V, Guyon G, Rodiere M, Segondy M. Human metapneumovirus infection in young children hospitalized with respiratory tract disease. Pediatr Infect Dis J. 2006;25(4):354-359.

12. Konig B, Konig W, Arnold R, Werchau H, Ihorst G, Forster J. Prospective study of human metapneumovirus infection in children less than 3 years of age. J Clin Microbiol. 2004;42(10):4632-4635.

13. Franz A, Adams O, Willems R, Bonzel L, Neuhausen N, Schweizer-Krantz S, Ruggeberg JU, et al. Correlation of viral load of respiratory pathogens and co-infections with disease severity in children hospitalized for lower respiratory tract infection. J Clin Virol. 2010;48(4):239245. 
14. Aberle JH, Aberle SW, Pracher E, Hutter HP, Kundi M, Popow-Kraupp T. Single versus dual respiratory virus infections in hospitalized infants: impact on clinical course of disease and interferon-gamma response. Pediatr Infect Dis J. 2005;24(7):605-610.

15. Lazar I, Weibel C, Dziura J, Ferguson D, Landry ML, Kahn JS. Human metapneumovirus and severity of respiratory syncytial virus disease. Emerg Infect Dis. 2004;10(7):1318-1320.

16. van Woensel JB, Bos AP, Lutter R, Rossen JW, Schuurman R. Absence of human metapneumovirus co-infection in cases of severe respiratory syncytial virus infection. Pediatr Pulmonol. 2006;41(9):872-874.

17. Garcia-Garcia ML, Calvo C, Perez-Brena P, De Cea JM, Acosta B, Casas I. Prevalence and clinical characteristics of human metapneumovirus infections in hospitalized infants in Spain. Pediatr Pulmonol. 2006;41(9):863-871.

18. Wolf DG, Greenberg D, Kalkstein D, Shemer-Avni Y, Givon-Lavi N, Saleh N, Goldberg MD, et al. Comparison of human metapneumovirus, respiratory syncytial virus and influenza A virus lower respiratory tract infections in hospitalized young children. Pediatr Infect Dis J. 2006;25(4):320-324.

19. Wilkesmann A, Schildgen O, Eis-Hubinger AM, Geikowski T, Glatzel T, Lentze MJ, Bode U, et al. Human metapneumovirus infections cause similar symptoms and clinical severity as respiratory syncytial virus infections. Eur J Pediatr. 2006;165(7):467-475.

20. Brand HK, de Groot R, Galama JM, Brouwer ML, Teuwen K, Hermans PW, Melchers WJ, et al. Infection with multiple viruses is not associated with increased disease severity in children with bronchiolitis. Pediatr Pulmonol. 2012;47(4):393-400.

21. Martin ET, Kuypers J, Wald A, Englund JA. Multiple versus single virus respiratory infections: viral load and clinical disease severity in hospitalized children. Influenza Other Respi Viruses. 2012;6(1):71-77.

22. Krasinski K, LaCouture R, Holzman RS, Waithe E, Bonk S, Hanna B. Screening for respiratory syncytial virus and assignment to a cohort at admission to reduce nosocomial transmission. J Pediatr. 1990;116(6):894898.

23. Madge P, Paton JY, McColl JH, Mackie PL. Prospective controlled study of four infection-control procedures to prevent nosocomial infection with respiratory syncytial virus. Lancet. 1992;340(8827):1079-1083.

24. Hall CB. Nosocomial respiratory syncytial virus infections: the "Cold War" has not ended. Clin Infect Dis. 2000;31(2):590-596.

25. Hall CB, Douglas RG, Jr. Modes of transmission of respiratory syncytial virus. J Pediatr. 1981;99(1):100-103.

26. Kristjansson S, Lodrup Carlsen KC, Wennergren G, Strannegard IL, Carlsen KH. Nebulised racemic adrenaline in the treatment of acute bronchiolitis in infants and toddlers. Arch Dis Child. 1993;69(6):650-654.

27. Lessler J, Reich NG, Brookmeyer R, Perl TM, Nelson $\mathrm{KE}$, Cummings DA. Incubation periods of acute respiratory viral infections: a systematic review. Lancet Infect Dis. 2009;9(5):291-300.

28. Reijans M, Dingemans G, Klaassen CH, Meis JF, Keijdener J, Mulders B, Eadie K, et al. RespiFinder: a new multiparameter test to differentially identify fifteen respiratory viruses. J Clin Microbiol. 2008;46(4):12321240.

29. Doan Q, Enarson P, Kissoon N, Klassen TP, Johnson DW. Rapid viral diagnosis for acute febrile respiratory illness in children in the Emergency Department. Cochrane Database Syst Rev. 2012;5:CD006452. 